\title{
Tiller recruitment patterns and biennial tiller production in prairie sandreed
}

\author{
J. R. HENDRICKSON, L. E. MOSER, AND P.E. REECE
}

Authors are rangeland scientist, Northern Great Plains Research Lab, USDA-ARS, Mandan, N. D. 58554; professor, Agronomy Department, University of Nebraska, Lincoln, Nebr., 68583; and associate professor, Panhandle Research and Extension Center, University of Nebraska, Scottsbluff, Nebr. 69361-4939 respectively. At the time of the research, the senior author was a research assistant, Agronomy Department, University of Nebraska, Lincoln, Nebr.

Abstract

Tiller recruitment is an essential process for ensuring the perenniality of grasses. The timing and extent of tiller recruitment and the role of biennial tillers must be documented for key range species. Prairie sandreed [Calamovilfa longifolia (Hook) Scribn.] is an important grass in the Nebraska Sandhills for both ecological functioning and as a forage. The objective of this study was to document tiller recruitment patterns and the occurrence and contribution of current year and biennial tillers to biomass production in prairie sandreed at 2 locations in Nebraska. Tiller recruitment was monitored at 2 -week periods throughout the growing season during a 2-year period. Newly emerged tillers were classified as intravaginal, extravaginal, or rhizomatous tillers and marked with colored wire. Prairie sandreed has an unimodal pattern of tiller recruitment and over $50 \%$ of the current year tillers emerged by mid-May and $80 \%$ by mid-June. Rate of tiller emergence and absolute number of emerged tillers were poorly correlated with short- and long-term precipitation totals $(\mathrm{r}<0.3 \mathrm{P}>0.20)$. The year after new tillers were marked, biennial tillers and tillers initiated during the current-year were counted and clipped in September for biomass determination. Biennial tillers made up only 6 and $20 \%$ of the total tiller emergence at these locations and were generally only $30 \%$ as large as the new tillers. Extravaginal tillers composed over $78 \%$ of the biennial tiller population as a result of both their dominance in emerging populations and the higher percentage of tillers that survived the winter. Current year tillers contributed the most to prairie sandreed forage production and their emergence was largely completed by mid-June. The lack of a relationship between tiller recruitment and precipitation patterns, combined with previous studies of prairie sandreed, indicates that tiller recruitment involves a process that begins the previous growing season.

Key Words: Warm-season grass, tiller demography, Calamovilfa longifolia (Hook.) Scribn., grassland ecology, population ecology/biology

The authors would like to thank Drs. D. Briske, R. Heitschmidt, J. Volesky and J. Stubbendieck for their comments on earlier versions of this manuscript, and $\mathrm{N}$. Mason for providing the Spanish translation of the abstract.

All programs and services of the U.S. Department of Agriculture are offered on a nondiscriminatory basis without regard to race, color, national origin, religion, sex, age, martial status, or handicap. This manuscript was published as the University of Nebraska Agricultural Research Division Journal Series No. 12350. Manuscript accepted 7 Dec. 1999.
Resumen

El renuevo de las macollas (número de macollas que brotan durante todo el periodo de crecimiento) es un proceso esencial para asegurar la perennidad de los pastos. La regulación del tiempo, la cantidad de renovación de las macollas, y el papel de las macollas bienales deben ser documentados para las especies claves de las praderas. Prairie sandreed [Calamovilfa longifolia (Hook) Scribn.] es un pasto importante en las lomas arenosas (sandhills) al oeste de Nebraska, no solo por su contribución ecológica sino también como forraje. Los objetivos de este estudio han sido el de documentar el patrón de renuevo de las macollas, la ocurrencia y la contribución de las macollas durante el presente año y las macollas bienales del año anterior en la producción de la biomasa del pasto prairie sandreed en dos localidades de Nebraska. El renuevo de las macollas fué determinado cada dos semanas durante la época de crecimiento del pasto y por un período de dos años. A medida que las macollas iban brotando fueron clasificadas en intravaginadas (crecimiento desde adentro de la vaina de la hoja) y extravaginadas (penetración de la vaina de la hoja) o rizomas e identificadas con alambres de colores. El pasto prairie sandreed posee un patrón unimodal en su renovación de las macollas; durante el presente año mas del $50 \%$ de sus macollas, brotaron a mediados de Mayo y el $80 \%$ a mediados de Junio. La proporción de la brotación de las macollas y el número absoluto de las macollas que brotaron estuvo pobremente correlacionado $(\mathrm{r}<0.3 \mathrm{P}>0.20)$ con la precipitación total a corto y a largo plazo. En el segundo año, las macollas bienales y las macollas que brotaron durante el presente año fueron contadas y cortadas para determinar la biomasa. Las macollas bienales representaron de un 6 al $20 \%$ del total de las macollas en las dos localidades, y fueron por lo general $30 \%$ tan grandes como las macollas nuevas. Las macollas extravaginadas formaron mas del $78 \%$ de la población de macollas bienales, debido a su caracter dominante para brotar y también a su alto porcentaje de sobrevivencia durante el invierno. Las macollas del presente año fueron las que mas contribuyeron a la producción del pasto forrajero sandreed, completando la mayor parte de su brotación a mediados de Junio. La carencia de relación entre el renuevo de las macollas y los patrones de la precipitación, combinado con resultados obtenidos en años anteriores, indican que el renuevo de las macollas está involucrado en un proceso el cual se inicia en el anterior período de crecimiento del pasto.

Prairie sandreed [Calamovilfa longifolia (Hook) Scribn.] is a widespread rhizomatous perennial grass on sandy soils in the Northern Great Plains of the United States. It is one of the most 
common grasses of the Nebraska Sandhills (Tolstead 1942) and together with sand bluestem [Andropogon gerardii var. pau cipilus (Nash) Fern.] and little bluestem [Schizachyrium scoparium (Michx.) Nash] provides $50-60 \%$ of the available forage in most years (Northup 1993). Tolstead (1942) and Hendrickson et al. (1998) described the developmental morphology of prairie sandreed.

Knowledge of tiller dynamics contributes to greater ecological understanding and more effective management of grasslands (Briske and Silvertown 1993, McKenzie 1997). Understanding tiller dynamics is critical in developing appropriate grazing strategies for rangelands (Cullan et al. 1999). Most perennial grasses have bimodal recruitment patterns with flushes of new tillers emerging during the spring and fall (Langer 1956, Briske and Butler 1989, Briske and Richards 1995). However, crested wheatgrass [Agropyron desertorum (Fisch. Ex Link) Schult.], bluebunch wheatgrass [Pseudoroegneria spicatum (Pursh) A. Löve] (Mueller and Richards 1986), and big bluestem [Andropogon gerardii Vitmann var. ger ardii] (McKendrick et al. 1975), only produced 1 annual cohort. These established patterns of tiller recruitment may be affected by defoliation which extends the recruitment period (Butler and Briske 1988), promotes additional tiller cohorts (Olson and Richards 1988a), and changes the timing of peak recruitment (Bullock et al 1994). Tiller recruitment is also a major method of perennial grass persistence (Hendrickson and Briske 1997) and annual tiller replacement is necessary to maintain tiller density (Olson and Richards 1988b). Reduction in tiller density reduces both current and future productivity since tiller density represents a pool of meristematic tissue for future growth (Murphy and Briske 1992).

Timing of tiller recruitment has a direct effect on tiller longevity and tiller yield. Tillers recruited in the fall often overwinter in the vegetative stage and resume growth the following spring (Briske 1991). These "biennial tillers" have been reported for certain grasses in the plains states. In the Kansas Flint Hills, a majority of indiangrass tillers [Sorghastrum nutans L. (Nash)] were biennial but big bluestem tillers only lived for 1 year (McKendrick et al. 1975). In the Nebraska Sandhills, biennial tillers were reported in prairie sandreed but not its co-dominant sand bluestem (Bredja et al. 1988, Cullan et al. 1999) and prairie sandreed in Montana did not produce biennial tillers (White 1977). Biennial tillers are important because they often have a greater dry weight, leaf number, and seed yield than tillers recruited during the growing season because they have more time for growth and development (Langer 1956).

Tiller type influences plant architecture (Briske 1991) and plant development (White 1977). Bunchgrasses are characterized by intravaginal tillers or tillers which arise from within the subtending leaf while sod forming grasses have more extravaginal and rhizomatous tillers (Briske 1991). Prairie sandreed has rhizamotous, intra- and extravaginal tillers similar to switchgrass (Panicum virgatum L.) (Brejda et al. 1988). Rhizomatous tillers in prairie sandreed have an increased probability of producing seedheads (White 1977) which has an adverse affect on nutritive value and palatability (Reece et al. 1999).

Despite the importance of prairie sandreed to the Nebraska Sandhills in particular and the Northern Great Plains in general, relatively little is known about its basic demographic patterns and the role of biennial tillers in biomass determination. The objective of this study was to evaluate tiller recruitment patterns in prairie sandreed, estimate the contributions of intravaginal, extravaginal, and rhizomatous tillers to overall tiller recruitment and determine the importance and contribution of biennial tillers to forage production.

\section{Materials and Methods}

Research was conducted in 1990 and 1991 at 2 University of Nebraska research locations. The Gudmundsen Sandhills Laboratory $\left(42^{\circ} 07^{\prime} \mathrm{N}, 101^{\circ} 43^{\prime} \mathrm{W}\right)$ is centrally located in the Nebraska Sandhills near Whitman, Nebr. and the Panhandle Experimental Range $\left(42^{\circ} 08^{\prime} \mathrm{N}, 103^{\circ}\right.$ $\left.43^{\prime} \mathrm{W}\right)$ is located near Mitchell in the Nebraska Panhandle approximately 240 $\mathrm{km}$ west of the Gudmundsen Sandhills Laboratory. There were 3 and 6 study sites located at the Gudmundsen Sandhills Laboratory and the Panhandle Experimental Range respectively. Study sites were located on Valentine fine sands (mixed, mesic typic Ustipsamments) at the Gudmundsen Sandhills Laboratory and Valent fine sands (mixed, mesic, ustic Torripsamment) at the Panhandle Experimental Range in areas dominated or co-dominated by prairie sandreed ( $\geq 50 \%$ of the cover). Dominance or co-dominance by prairie sandreed is typical of a majority of Sandhills vegetation that is in mid to high seral stage.
Average annual precipitation at the Gudmundsen Sandhills Laboratory is 514 $\mathrm{mm}$ and $70 \%$ falls during the growing season (April through September). At the Panhandle Experimental Range, the average annual precipitation is $393 \mathrm{~mm}$ with the same distribution pattern. Precipitation from 1 April to 30 September was 76, 119, and $90 \%$ of the 30 -year average for the Gudmundsen Sandhills Laboratory in 1990, 1991, and 1992 respectively. Precipitation during the same years, at the Panhandle Experimental Range, was 98, 138 , and $96 \%$ of the 30 -year average. Precipitation data were collected electronically during the growing season from a weather station at the Gudmundsen Sandhills Laboratory headquarters and from a rain gauge located $1.25 \mathrm{~km}$ south of the Panhandle Experimental Range study site. Thirty-year averages were taken from the closest U.S. Weather Service stations located $20 \mathrm{~km}$ northeast of the Gudmundsen Sandhills Laboratory and $10.5 \mathrm{~km}$ southeast of the Panhandle Experimental Range.

Study sites at the Gudmundsen Sandhills Laboratory were excluded from livestock grazing for 5 years previous to the initiation of the study. At the Panhandle Experimental Range, study sites were grazed as part of a deferred rotation for 15 years previous to the study at a stocking rate of $1.01 \mathrm{AUM} / \mathrm{ha}$. However, livestock were excluded from the sites during the investigation.

Twelve permanent $0.5 \mathrm{~m}^{2}$ quadrats (70.5 $\mathrm{cm} \times 70.5 \mathrm{~cm}$ ) were randomly located within the study sites during the first week of May 1990 at each location. There were a total of 4 quadrats within each of the 3 study areas at the Gudmundsen Sandhills Laboratory and 2 quadrats within each of the 6 study areas at the Panhandle Experimental Range. Quadrats were monitored for new tiller emergence at 2-week intervals, from mid-May through midSeptember during the 1990 growing season. Newly emerged tillers were classified into 3 categories (intravaginal, extravaginal, or rhizomatous) based on the position of the emerging tiller. Tillers that emerged from within the subtending leaf sheath were considered intravaginal tillers while extravaginal tillers emerged through the subtending leaf sheath (Briske 1991). Tillers that emerged more than $3 \mathrm{~cm}$ from the nearest existing tiller were considered to be rhizomatous. Colored wires were placed on the base of each new tiller to indicate category and date of emergence.

In 1991, these same 12 quadrats at each location were evaluated to determine the 
winter survival of the 1990 tillers by counting the number of live tillers. Surviving tillers were classified as biennial. Counts were done in mid-April, midMay and at the end of September in 1991. In September, biennial and new tillers were clipped separately, separated into vegetative and reproductive tillers, dried for 3 days at $55^{\circ} \mathrm{C}$, and weighed.

In 1991,12 new $0.5 \mathrm{~m}^{2}$ quadrats were randomly located in the same study areas at each location and monitoring was conducted in the same manner as in 1990 except that at the Panhandle Experimental Range, monitoring of tiller emergence began in mid-April rather than mid-May. Evaluation of these 12 quadrats for biennial tillers was conducted in April and September of 1992.

Daily tiller initiation rate was calculated as follows:

Daily tiller initiation rate $=$

number of new tillers $1.0 \mathrm{~m}^{-2}$

number of days since previous sampling

The number of tillers emerged was converted from $0.5 \mathrm{~m}^{-2}$ to the more recognizable $1.0 \mathrm{~m}^{-2}$. Based on the 1991 tiller emergence patterns at the Panhandle Experimental Range, 1 April was selected as the beginning date for calculating rate of tiller initiation for the first sampling period each year.

Tiller emergence was analyzed as a split plot in time with time being a sub-plot factor to allow for a greater resolution of time (Briske and Hendrickson 1998). Differences between locations were analyzed using study site nested within location as an error term and differences between time and location by time were analyzed using time by study site nested within location as an error term. A majority of tiller emergence occurred early in the growing season and so only the first 4 time periods were included in the data analysis. Tiller emergence data were log transformed to correct for a non-normal distribution. Results are presented using non-transformed data for clarity of presentation. Standard errors were calculated across the first 4 time periods. Tillers within each type category were pooled over time periods, because of small sample sizes in some time periods and categories, and analyzed for differences between locations and study sites within location. Analysis was conducted using the SAS PROC GLM module (SAS 1989). Means separation was done using the Student-Newman-Keuls' test.

The absolute number of tillers that emerged and the rates of tiller emergence were correlated with the sum of the precipitation received during the 14 and 30- day intervals prior to the sampling period. Tiller emergence was also correlated with the 30-year average precipitation on a monthly basis. Correlations were done using the PROC CORR procedure in SAS (SAS 1989). Significance was determined at $\mathrm{P} \leq 0.05$ unless otherwise noted. Standard errors were calculated averaged across sampling dates.

The Panhandle Experimental Range had relatively few biennial tillers. Therefore, most of the data used in evaluating the contribution of biennial tillers came from the Gudmundsen Sandhills Laboratory. Standard errors used in the comparison of the contributions of new and biennial tillers to biomass and tiller numbers were calculated across study sites and quadrats. Standard errors, used in evaluating the number and percent of biennial tillers from each sampling date, were calculated across study sites and quadrats within sampling dates.

\section{Results}

\section{Emergence date and category:}

There were no significant differences in tiller recruitment between locations in 1990 ( $P$ > 0.10); however, tiller emergence during the 1990 growing season was $160 \%$ greater at Gudmundsen Sandhills Laboratory than at Panhandle Experimental Range (Fig. 1). In 1991, tiller emergence declined by $25 \%$ at the Gudmundsen Sandhills Laboratory but nearly doubled at the Panhandle
Experimental Range so total tiller emergence was very similar between locations (P > 0.75) (Fig. 2). Over $50 \%$ of the total tiller emergence for the season occurred by mid-May for both years and locations (Fig. 1 and 2). After early June, tiller emergence generally declined and remained low for the remainder of the growing season.

Time, but not location by time, had a significant effect on tiller recruitment in 1990, thus tiller emergence was pooled over location (Fig. 1). Each of the first 3 sampling periods in 1990 had significantly greater tiller recruitment than the subsequent period (Fig. 1). In 1991, there was a location by time interaction (Fig. 2) and tiller recruitment patterns were analyzed separately at each location. The pattern of tiller emergence at the Gudmundsen Sandhills Laboratory was similar to 1990 although there were no significant differences between the mid and late June time periods (Fig. 2). At the Panhandle Experimental Range, tiller emergence was similar in early and mid June and those time periods were significantly greater than late June (Fig. 2).

The Gudmundsen Sandhills Laboratory had significantly more extravaginal and rhizomatous tillers than the Panhandle Experimental Range in 1990. However, intravaginal tiller number was influenced more by site within location than by location. In 1991, the Gudmundsen Sandhills Laboratory had significantly more intravaginal tillers than the Panhandle Experimental Range, but the number of

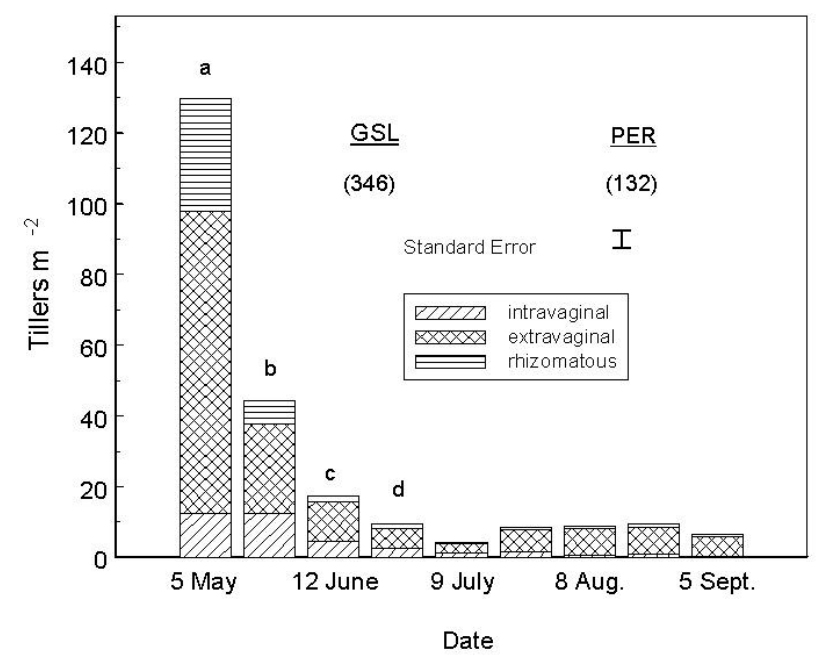

Fig. 1. Number of tillers that emerged $\left(\mathrm{m}^{-2}\right)$ on each monitoring date in 1990 pooled across locations for the Gudmundsen Sandhills Laboratory (GSL) and the Panhandle Experimental Range (PER). Newly emerged tillers were classified as either intravaginal, extravaginal or rhizomatous at each monitoring date. Numbers in parentheses are the total number of tillers that emerged (tillers $\mathrm{m}^{-2}$ ). Data was pooled over locations for each emergence date. Bars with different letters represent significant differences $(P<0.05)$ in total tiller emergence among the first $\mathbf{4}$ dates. 


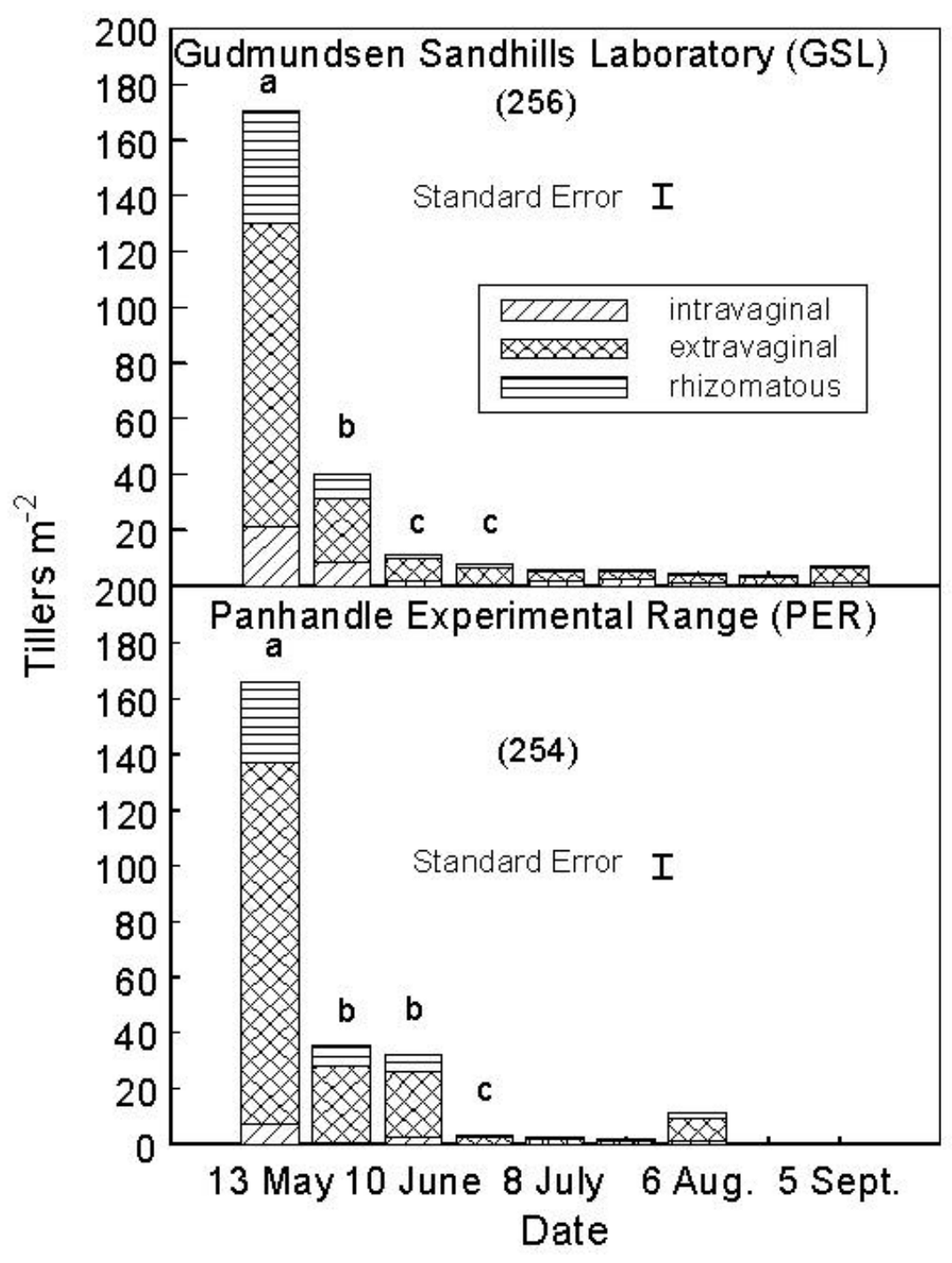

Fig. 2. Number of tillers that emerged $\left(\mathrm{m}^{-2}\right)$ on each monitoring date in 1991 at the Gudmundsen Sandhills Laboratory (GSL) and the Panhandle Experimental Range (PER). Newly emerged tillers were classified as either intravaginal, extravaginal or rhizomatous tillers at each monitoring date. Number in parentheses is the total number of tillers that emerged (tillers $\mathrm{m}^{-2}$ ) during the growing season at each location. Data was not pooled because of a location by time interaction. Bars with different letters represent significant differences $(P<\mathbf{0 . 0 5})$ in total tiller emergence between the first 4 dates for each location. extravaginal tillers was similar between locations. The number of rhizomatous tillers, in 1991, was affected more by site within location than by location.

Over the 2-year period, extravaginal tillers made up more than $63 \%$ of all tillers recruited at the Gudmundsen Sandhills Laboratory and over $75 \%$ of all tillers recruited at the Panhandle Experimental Range. Extravaginal tillers comprised more than $50 \%$ of the emerged tillers at any single sample date (Figs. 1 and 2) and they were the only tiller category to emerge from 24 July to 28 August 1990 and from 6 August to 19 August 1991 at the Panhandle Experimental
Range. Rhizomatous tillers were the next largest category and they were 20 and $18 \%$ of total tiller emergence at the Gudmundsen Sandhills Laboratory and the Panhandle Experimental Range, respec- tively. Intravaginal tillers contributed the least number of tillers at both locations with only $7 \%$ and $16 \%$ of the emerged tillers being intravaginal at the Panhandle Experimental Range and the Gudmundsen Sandhills Laboratory respectively.

\section{$\underline{\text { Tiller initiation correlations }}$}

Absolute tiller recruitment and tiller initiation rate were poorly correlated with 14-day and 30-day precipitation amounts (Fig. 3). Correlation coefficients were less than $0.3(\mathrm{P}>0.20)$. An exception was tiller initiation rate and 30-day precipitation at Gudmundsen Sandhills Laboratory in $1991(\mathrm{r}=0.43, \mathrm{P}=0.07)$. Correlations between tiller emergence and longer-term precipitation data (monthly totals over 30 years) was also low $(\mathrm{r}<0.30, \mathrm{P}>0.20)$.

\section{Biennial tiller yield:}

Most tillers did not survive the following winter. Only $22 \%$ of the tillers, which emerged during the 2-year study, became biennial tillers at the Gudmundsen Sandhills Laboratory and only 6\% at the Panhandle Experimental Range. In 1991, less than $1 \%$ of all the tillers that emerged during the growing season at the Panhandle Experimental Range became biennial tillers. Because of their minimal contribution to numbers and biomass at the Panhandle Experimental Range, those biennial tillers were not included in any of the data analysis regarding biennial tillers. Approximately $30 \%$ of tillers harvested in 1991 from plots established in 1990 at the Gudmundsen Sandhills Laboratory were biennial tillers but this had declined to $20 \%$ in 1992 (Fig. 4). Biennial tillers made up $12 \%$ of the yield from all live prairie sandreed tillers in 1991 and $6 \%$ of the 1992 biomass at the Gudmundsen Sandhills Laboratory (Fig. 4).

Yields of biennial tillers may have decreased because of harvesting in September rather than earlier in the growing season. However, there were no significant differences $(\mathrm{P}>0.05)$ at the Gudmundsen Sandhills Laboratory when the number of biennial tillers recorded
Table 1. Mean individual tiller weights for tillers surviving from the previous year (biennial) and tillers that emerged during the current year at the Panhandle Experimental Range (PER) and Gudmundsen Sandhills Laboratory (GSL). Biennial tillers recorded in 1991 and 1992 had emerged in 1990 and 1991 respectively.

\begin{tabular}{lcccc}
\hline \hline \multirow{2}{*}{ Harvest Date } & \multicolumn{2}{c}{ PER } & \multicolumn{2}{c}{ GSL } \\
\cline { 2 - 3 } 1991 & Biennial Tillers & Current Year Tillers & Biennial Tillers & Current Year Tillers \\
\hline 1992 & $78 \pm 4$ & $759 \pm 48$ & $131 \pm 3$ & $443 \pm 33$ \\
\hline
\end{tabular}


early in the season was compared to biennial tillers recorded later in the growing season. Tillers that emerged during the current growing season were 30 to $880 \%$ heavier then the biennial tillers (Table 1). These extremes were both recorded at the Panhandle Experimental Range but at the Gudmundsen Sandhills Laboratory, current year tillers were 230 to $260 \%$ heavier than the biennial tillers.

At the Gudmundsen Sandhills Laboratory, tiller cohorts that emerged early in the growing season the previous year made up the largest percentage of biennial tillers (Fig. 5). However, tillers that emerged later in the growing season were more likely to become biennial tillers (Fig. 5). May tiller cohorts made up approximately $33 \%$ of the biennial tillers in 1991 and $60 \%$ of the biennial tillers in 1992. The 1991 biennial tiller population had a large contribution from tiller cohorts that emerged later in the season in 1990 because of increased tiller emergence later in the season combined with increased potential for these tillers to become biennial. Over $70 \%$ of the biennial tillers at Gudmundsen Sandhills Laboratory were from the extravaginal tiller category (Table 2 ) because of the greater number of extravaginal tillers. Extravaginal tillers had the highest survival rate in the 1990 cohort but survival rates were similar between the extravaginal and intravaginal categories in the 1991 tiller cohort (Table 2).

\section{Discussion}

The unimodal pattern of tiller emergence in prairie sandreed differs from the more commonly reported bimodal tillering pattern of other perennial grasses in temperate zones (Langer 1963, Butler and Briske 1988, Briske and Richards 1995). However, unimodal tillering patterns have been reported for the $\mathrm{C}_{3}$ grasses, crested wheatgrass, and bluebunch wheatgrass, (Mueller and Richards 1986). In a Kansas study of $2, \mathrm{C}_{4}$ grasses, indiangrass had a

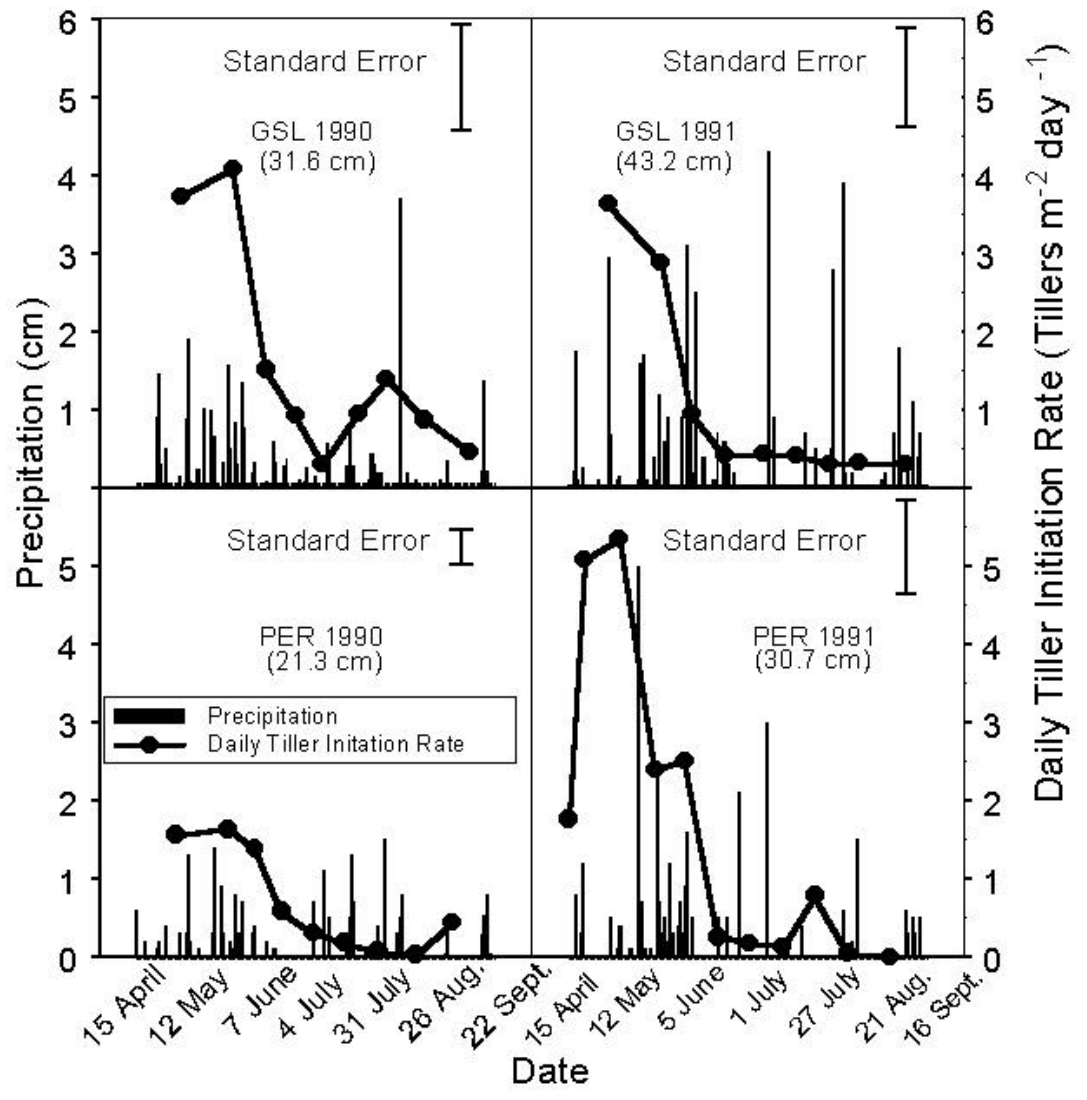

Fig. 3. Daily tiller initiation rates (tillers $\mathrm{m}^{-2} \mathrm{day}^{-1}$ ) and precipitation events $(\mathrm{cm})$ during the growing season at the Gudmundsen Sandhills Laboratory and the Panhandle Experimental Range during the 1990 and 1991 growing seasons. The numbers in parenthesis represent total precipitation received during the growing season at each location and each year.

bimodal tiller recruitment pattern while big bluestem, had a unimodal pattern (McKendrick et al. 1975).

Regionally, patterns of tiller emergence may be linked to precipitation patterns or the length of the growing season (Briske 1991). In our more site specific study, tiller emergence during the growing season and the rate of daily tiller emergence were poorly correlated with either yearly or 30-year average precipitation events which was similar to reports from sideoats grama [Bouteloua curtipendula (Michx.)

Table 2. Percentage of tillers that emerged during the preceding year and survived to become biennial tillers from each tiller category and the percentage that each tiller category contributed to the composition of the biennial tiller population in 1991, 1992 and averaged over both years at the Gudmunsen Sandhills Laboratory. Data from the Panhandle Research Range not presented.

\begin{tabular}{|c|c|c|c|c|c|c|}
\hline \multirow[b]{2}{*}{ Tiller Category } & \multirow{2}{*}{\multicolumn{2}{|c|}{$\begin{array}{c}\text { Survival Rate } \\
1991 \\
\end{array}$}} & \multirow[b]{2}{*}{ Average } & \multicolumn{3}{|c|}{$\begin{array}{l}\text { Composition of the } \\
\text { Biennial Tiller Population }\end{array}$} \\
\hline & & & & 1990 & 1991 & Average \\
\hline & & & -----6 & $-5-2$ & $-5-2$ & \\
\hline Extravaginal & $27 \pm 2.2$ & $27 \pm 3.8$ & $27 \pm 2.0$ & $86 \pm 2.7$ & $70 \pm 1.3$ & $78 \pm 3.9$ \\
\hline Intravaginal & $8 \pm 2.7$ & $25 \pm 2.2$ & $16 \pm 4.2$ & $6 \pm 2.2$ & $15 \pm 1.3$ & $10 \pm 2.3$ \\
\hline Rhizomatous & $9 \pm 4.7$ & $17 \pm 2.3$ & $13 \pm 2.9$ & $8 \pm 2.7$ & $15 \pm 2.6$ & $12 \pm 2.4$ \\
\hline
\end{tabular}

Torr.] (Hendrickson 1996). Moreover, although both locations received more precipitation during the 1991 than in the 1990 growing season, total tiller emergence decreased from 1990 to 1991 at Gudmundsen Sandhills Laboratory while increasing by $100 \%$ at Panhandle Experimental Range. However, Cullan et al. (1999) suggested that soil moisture and the ability of plants to absorb soil moisture may be critical factors in determining recruitment in prairie sandreed. The sandy substrate at both locations complicates the response to precipitation because its coarse texture allows for deep percolation of even minor rainfall events (Barnes and Harrison 1982). Thus, frequency of precipitation events may be more important that total precipitation.

Biennial tillers did not make a large contribution to tiller recruitment (6 to $22 \%$ ) or aboveground biomass, which was surprising since the longer season of growth and development is often considered to give a growth advantage to biennial tillers (Langer 1956, Briske 1991). However in our study, new tillers were $200 \%$ heavier 


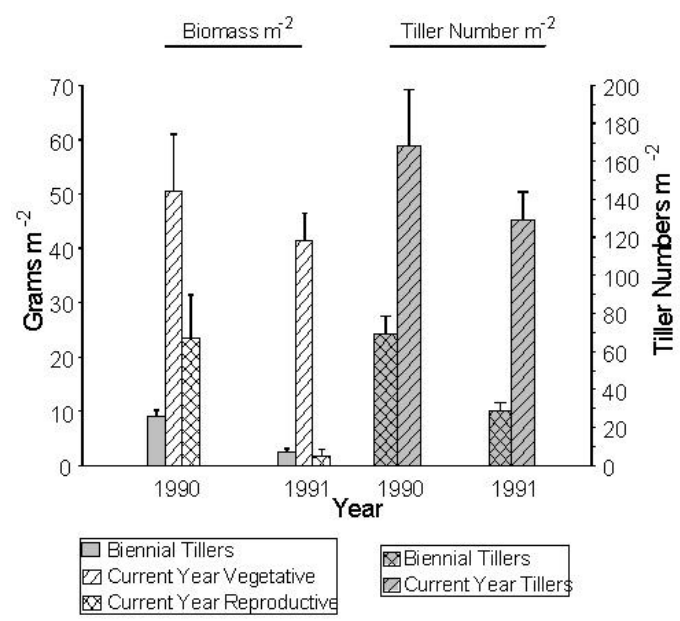

Fig. 4. Contribution of current year tillers and biennial tillers to biomass $\left(\mathrm{g} \mathrm{m}^{-2}\right)$ and tiller numbers $\mathrm{m}^{-2}$ at the Gudmundsen Sandhills Laboratory in 1991 and 1992. Biennial tillers had emerged during the previous growing season (1990 and 1991 respectively) and survived overwinter. Current year tillers were tillers that emerged in the 1991 and 1992 growing seasons. Current year tiller biomass was separated into vegetative and reproductive components but biennial tiller biomass was pooled over both components. prairie sandreed with an alternative population maintenance mechanism. This observation is difficult to assess because of the limited time frame of the experiment but a majority of biennial tillers remained vegetative even at the end of their second growing season. Although the contribution of axillary buds and tiller recruitment to population persistence has been explored (Hendrickson and Briske 1997), there is limited information regarding the role of tiller longevity in this regard. There have been reports of tiller ages of up to 5 years in northern wheatgrass [Agropyron dasystachyum (Hook) Scribn.) in Saskatchewan, Canada (Zhang and Romo 1995) and 3-year old western wheatgrass (Agropyron smithii Rydb.) tillers were observed in Montana (White 1977). These reports are from areas with more severe winter climates and contrast with lifespan of 1-2 years in more moderate climates (Langer 1956, Briske 1991, than biennial tillers thus early emergence did not seem to give a growth advantage to biennial tillers. If biennial tillers died prior to the harvesting date in September, their numbers and biomass could have been underestimated. However, biennial tillers numbers were generally similar between the early (April and May) and September monitoring dates.

The largest percentage of biennial tillers were from tiller cohorts that emerged early in the previous growing season because of the larger tiller recruitment. However, later emerging tillers were more likely to become biennial. Although, tillers which emerge early in the growing season generally have the greatest probability of becoming reproductive (Briske 1991), in our study a majority of biennial tillers were still vegetative when they were harvested at the end of the second growing season. A study of morphological development in prairie sandreed conducted during the same time period at Gudmundsen Sandhills Laboratory also indicated a majority of tillers remained vegetative throughout the growing season (Hendrickson et al. 1998). This suggests that the limited number of biennial tillers in prairie sandreed may not be a result of the tillers completing their life cycle but rather because of the small number of tillers recruited late in the growing season when they were more likely to become biennial. In Montana, $\mathrm{C}_{3}$ grass tillers took $2-3$ years to flower and $\mathrm{C}_{4}$ grass tillers took $1-2$ years although the results varied by species (White 1977).

Biennial tillers may represent a small pool of long-lived tillers that provide

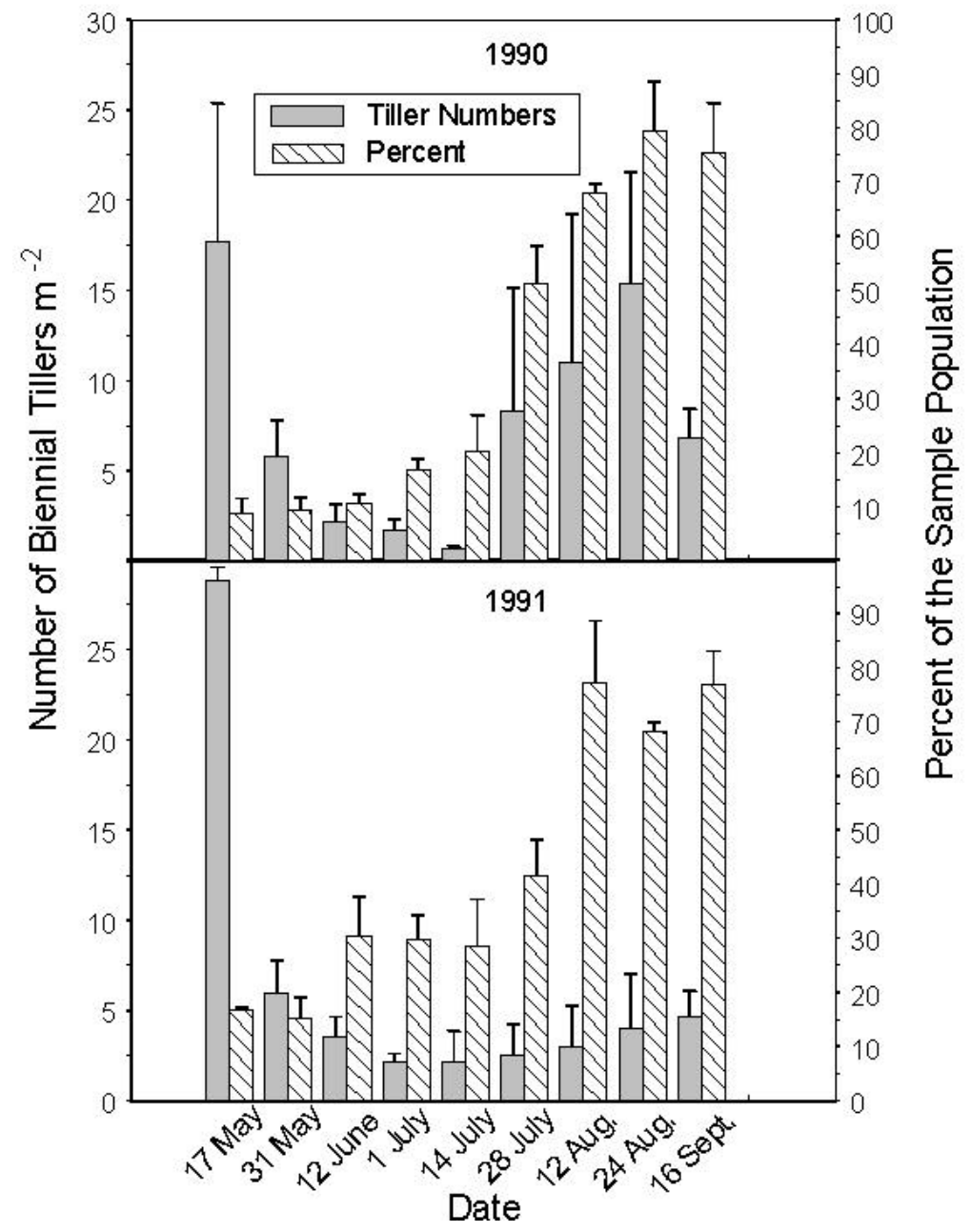

Fig. 5. The number and percent of new tillers $\mathrm{m}^{-2}$ marked on each monitoring date in 1990 and 1991 that survived overwinter and became biennial tillers the following year at the Gudmundsen Sandhills Laboratory. 
Briske and Richards 1995). From a practical point of view, a majority of the prairie sandreed tillers appeared to function as annual tillers similar to reports of prairie sandreed tillers in Montana (White 1977).

The limited contribution of biennial tillers in our study emphasized the importance of tillers initiated during the current year to tiller density and productivity. However tillers, which emerge during the growing season, are often initiated early and make some limited subterranean growth in the previous growing season (Bredja et al. 1988). Therefore, stress that occurs during this crucial time period early in the growing season may affect tiller numbers into the following growing season. For example, tiller and axillary bud numbers of prairie sandreed per unit area decreased when prairie sandreed and its associated species were clipped early in the growing season (June) over a 3-year period (Mullahey et al. 1991). Organic reserves of prairie sandreed were also adversely affected by a single grazing event in June or July but not August (Reece et al. 1996). These responses collectively indicate that tiller numbers during the year may be determined relatively early in the previous growing season. Consideration of the effects of environmental variables and management over multiple years needs to be incorporated into current management decisions.

\section{Conclusions}

In prairie sandreed, the tillering pattern and role of biennial tillers contrasts with patterns observed in other species (Langer 1956, Briske 1991). Prairie sandreed has a unimodal tillering pattern and a majority of tillers do not survive over winter. The few biennial tillers that are produced are small and make a minor contribution to biomass production as opposed to tillers that emerge during the growing season. The developmental morphology of prairie sandreed and the low correlations with precipitation indicate current-year tiller production may be linked to conditions in previous years. Given the importance of prairie sandreed for ecological functions and as a forage resource, quantifying the effects of preceding and current-year management as well as environmental variables on tiller emergence is warranted.

\section{Literature Cited}

Barnes, P. W. and A. T. Harrison. 1982. Species distribution and community organization in a Nebraska Sandhills mixed prairie as influenced by plant/soil-water relationships. Oecologia 52: 192-201.

Brejda, J. J., L. E. Moser, and S. S. Waller. 1988. Rhizome and tiller development of three Nebraska Sandhills warm-season grasses. p. 52. In: Thomas B. Bragg and James Stubbendieck (eds.), Proc. 11th North American Prairie Conference, Univ. of Nebr. Printing, Lincoln, Nebr.

Briske, D. D. 1991. Developmental morphology and physiology of grasses. Grazing Management: an ecological perspective. pp. 85-108. (Eds. R.K. Heitschmidt \& J.W. Stuth). Timber Press, Portland, Ore.

Briske, D. D. and J.L. Butler. 1989. Densitydependent regulation of ramet populations within the bunchgrass Schizachrium scopari $u m$ : interclonal versus intraclonal interference. J. of Ecol. 77:963-974.

Briske, D. D. and J.R. Hendrickson. 1998. Does selective defoliation mediate competitive interactions in a semiarid savanna? A demographic evaluation. J. of Veg. Sci. 9:611-622.

Briske, D. D. and J.H. Richards. 1995. Plant responses to defoliation: A physiological, morphological and demographic evaluation. In: (eds. D.J. Bedunah and R.E. Sosebee), pp. 635-710. Wildland Plants: Physiological ecology and developmental morphology. Soc. of Range Manage., Denver, Colo.

Briske, D.D. and J.W. Silvertown. 1993. Plant demography and grassland community balance: the contribution of popuation regulation mechanisms. In: Proceedings of the XVII Internat. Grassl. Congr., pp. 291-298. New Zealand.

Bullock, J. M., B. Clear Hill, and J. Silvertown. 1994. Tiller dynamics of two grasses- responses to grazing, density and weather. J. of Ecol. 82:331-340.

Butler, J.L. and D.D. Briske. 1988. Population structure and tiller demography of the bunchgrass Schizachyrium scoparium in response to herbivory. Oikos 51:306-312.

Cullan, A.P., P.E. Reece, and W.H. Schacht. 1999. Early summer grazing effects on defoliation and demography of prairie sandreed. J. Range Manage. 52:447-453.

Hendrickson, J.R. 1996. Mechanisms of persistence and species replacement in population of Bouteloua curtipendula with contrasting grazing histories. Ph.D. Diss., Texas A\&M Univ., College Station, Tex.

Hendrickson, J.R. and D.D. Briske. 1997. Axillary bud banks of two semiarid perennial grasses: occurrence, longevity, and contribution to population persistence. Oecologia 110:584-591.
Hendrickson, J.R., L.E. Moser, K.J. Moore and S.S. Waller. 1998. Morphological development of two warm-season grasses in the Nebraska Sandhills. J. Range Manage. 51:456-462.

Langer, R.H.M. 1956. Growth and nutrition of timothy (Phleum pratense)I. The life history of individual tillers. Annu. of Applied Biol. 44:166-187.

Langer, R.H.M. 1963. Tillering in herbage grasses. Herbage Abstr. 33:141-148.

McKendrick, J.D., C.E. Owensby and R.M. Hyde. 1975. Big bluestem and indiangrass vegetative reproduction and annual reserve carbohydrate and nitrogen cycles. AgroEcosystems 2:75-93.

McKenzie, F.R. 1997. Influence of grazing frequency on intensity of tiller appearance and death rates of Lolium perenne L. under subtropical conditions. Australian J. Agr. Res. 48:337-342.

Mueller, R.J. and J.H. Richards. 1986. Morphological analysis of tillering in Agropyron spicatum and Agropyron deserto rum. Annu. Bot. 58:911-921.

Mullahey, J. J., S. S. Waller, and L. E. Moser. 1991. Defoliation effects on yield and bud and tiller numbers of two Sandhills grasses. J. Range Manage. 44:241-245.

Murphy, J.S. and D.D. Briske. 1992. Regulation of tillering by apical dominance: Chronology, interpretive value, and current perspectives. J. Range Manage. 45:419-429.

Northup, B.K. 1993. Utilization of native forages of the Nebraska Sandhills by yearling cattle. Ph.D. Diss. University of Nebraska, Lincoln, Nebr.

Olson, B.E. and J.H. Richards. 1988a. Annual replacement of the tillers of Agropyron desertorum following grazing. Oecologia 76:1-6.

Olson, B.E. and J.H. Richards. 1988b. Tussock regrowth after grazing: intercalary meristem and axillary bud activity of tiller of Agropyron desertorum. Oikos 51: 374-382.

Reece, P.E., T.L. Holman, and K.J. Moore. 1999. Late-summer forage on prairie sandreed dominated rangeland after spring defoliation. J. Range Manage. 52:228-234.

Reece, P.E., J.E. Brummer, R.K. Engel, B.K. Northup, and J.T. Nichols. 1996. Grazing date and frequency effects on prairie sandreed and sand bluestem. J. Range Manage. 49:112-116.

SAS Institute. 1989. SAS user's guide: statistics (Version $61^{\text {st }}$ ed.) SAS Institute Inc. Cary, N.C

Tolstead, W.L. 1942. Vegetation of the northern Cherry County, Nebraska. Ecol. Monogr. 12:255-292.

White, L. M. 1977. Perenniality and development of shoots of 12 forage species in Montana. J. Range Manage. 30:107-110.

Zhang, J. and J. T. Romo. 1995. Impacts of defoliation on tiller production and survival in northern wheatgrass. J. Range Manage. $48: 115-120$. 